\title{
THEORETICAL BACKGROUND FOR INVESTIGATION AND PROMOTION OF ENGINEERS COMPETITIVENESS IN EDUCATION
}

\author{
Irena Katane ${ }^{1}$, Regina Baltusite ${ }^{2}$, Edgars Katans ${ }^{3}$ \\ ${ }^{1,2}$ Latvia University of Agriculture, Latvia; ${ }^{3}$ IT company "Autentica”, Latvia \\ irena.katane@inbox.lv, rilagora@inbox.lv, edgars.katans@inbox.lv
}

\begin{abstract}
Nowadays, there is a great demand for engineers in various fields of specialization. This brings up the question whether it is determined by the fact that, due to various reasons, higher education institutions do not train a sufficient number of the demanded specialists, or the reason is that the specialists (engineers) trained are not able to compete, as they do not meet the demands of the society, job market (including the employers) and the professional environment. This issue determines the topicality of theoretical and empirical investigation of the competitiveness of engineers. The aim of this report is to provide a theoretical basis for the competitiveness of engineers and the possibilities of its promotion in terms of various aspects. The results of theoretical researches confirm that pedagogical and psychological science validates the competitiveness of engineers in terms of three aspects: the competitiveness of a personality; the competitiveness of a specialist in the broad sense of the term; the competitiveness of an engineer with the focus on the engineering specialization in the engineering science. It is not only important to study the competitiveness of an engineer, but also to provide a scientific background for possible methods, which could be used to promote the competitiveness during the process of education and professional growth based on modern learning theories and concepts.
\end{abstract}

Keywords: engineer competitiveness, marketability, employability, competence.

\section{Introduction}

Contemporary social sciences, including pedagogy and psychology, carry out researches in the field of competitiveness. The topicality of such studies is determined by the inconsistency of globalization and globalization processes and their influence over sustainable development and competitiveness of the society. The more competitive each member of the society is, the more competitive is the society as such. The same can be told about the competitiveness of any enterprise. The fact that a person is self-developing both as a personality and as a specialist along with the environment of his or her life and professional activity means that this interaction is mutual, i.e., not only the competitiveness of each society or enterprise is determined by the competitiveness of each individual person, but the constantly changing social and professional environment is also impacting the competitive ability of each person substantially.

Nowadays, there is a great demand for engineers in various fields of specialization. This brings up the question whether it is determined by the fact that due to various reasons higher education institutions do not train a sufficient number of demanded specialists, or the reason is that the specialists (engineers) trained are not able to compete, as they do not meet the demands of the society, job market (including the employers) and the professional environment. This issue determines the topicality of theoretical and empirical investigation of the competitiveness of engineers.

The aim of this article is to provide a theoretical basis for the competitiveness of engineers and the possibilities of its promotion in terms of various aspects.

\section{Materials and methods}

In the result of theoretical studies, 3 aspects can be identified as the basis for the engineer's competitiveness: 1) an engineer as a self-reliant, competitive personality; 2) an engineer as a competitive specialist in the broad sense of the term; 3) an engineer as a competitive specialist in certain field of his activity (for example, programming, machine engineering, engineering sciences etc.) and environment. This report will validate the engineer competitiveness in terms of all the three aspects.

Theoretical base of competitiveness research in educational sciences:

- Methodological Approach to the Theoretical Substantiation and Studies of the Personality Competitiveness [1-5];

- Methodological Approach to the Theoretical Substantiation and Studies of the Specialist Competitiveness [6-10]. 
- Concept of Competence [11-13] and Concept of Competency [1;14] as an Integral Part of Competitiveness $[3 ; 5 ; 6]$.

Research goal: to elaborate a theoretical base for researching and promoting of the engineer's competitiveness in professional education and professional development.

Research method: studying, analysing and evaluation of scientific literature.

\section{Results and discussion}

It is important to demonstrate the complexity of the term in validating the engineer's competitiveness.

L. Mitina, a researcher in the field of concurentology, has defined personal competitiveness as the ability of a person to maximally enlarge abilities for fulfilling himself or herself as a personality, promoting his or her multisided professional and ethical development. A competitive personality is a reflexive personality, which is able: 1) to organise own work and behaviour independently, including the professional activity in situations of unstable environment; 2) to change the way of thinking and attitude, as a competitive personality is open to new type of thinking, non-traditional approaches in problem solving and adequate reaction to non-standard situation [5].

Competitiveness is an aggregate of the integrative personal qualities, which ensures the vital capacity of this personality, including development and self-fulfilment, in the dynamic environment conditions. A competitive personality of a new type is able to cooperate, is helpful, able to maintain the balance between I-ego and I-eco in terms of thinking and acting. From the point of view of a new paradigm, a competitive personality in self-development strives to compete with oneself rather than with the others, this person is: 1) struggling with own failures, faults, inability or unwillingness to do something important or necessary; 2) a goal-oriented person who has a clear view of the future goals; 3 ) creative and flexible in thinking and acting, therefore this person is able to solve problems that occur in unusual, non-standard situations; 4) able to take decisions and bear responsibility, 5) a responsible person whom you can rely on and whom you can trust $[3 ; 6]$.

A competitive specialist is: 1) aware of own resources, potential career development and abilities; 2) able to evaluate the current situation, timely (seeing a step ahead) understands, analyses and forecasts the development abilities and threats in the professional environment; 3) ready to change, learn, improve professional skills if necessary, to acquire new qualifications and to change the working environment; 4) not afraid to dare, to come up with innovative and creative ideas in order to be able to change some of own life activities, including professional activities or working environment, and to achieve its sustainability; 5) open for cooperation with colleagues, clients etc.; 6) able to see the competitors as cooperation partners and to work as a team; 7) demanding, and first of all demanding to oneself; 8) not afraid to undertake additional duties and responsibilities if the situation determines such need, 9) able to become the leader of a social group and/or the leader for the task; 10) also able to critically evaluate the quality and marketability of the offered service(s) or the produced product(s), ensuring that his professional activity and the results of this activity are marketable. A competitive specialist knows how and can harmonize his career goals with the goals of the society, of the company; feels responsible for the professional activity and its results; cares about the quality of his work; can adequately evaluate own skills as the professional, including professional competency. A competitive specialist is honoured by the others and honours himself [7].

The competitiveness of an engineer in psychology is explained as an internal system of the personality, which has various indications. The competitiveness of an engineer is formed and developed in interaction with a multiple-context professional environment, where we can identify a psychological, economical, informational, social context, as well as a legally defined regulatory environment context, where an engineer as a specialist tries to approve his professionality and gain achievements. At the same time, the competitiveness of an engineer can also affect the competitiveness of the professional environment - a company, an organisation. Thus, the competitiveness of engineers cannot be detached from the environmental context where they want to gain the competition benefits in their purposeful, value-oriented activity based on professional standards, ideals, samples etc. [9].

Many authors replace the notion of the specialist's competitiveness by the notions as follows: 
- marketability in the job market and society in total $[5 ; 10 ; 15]$;

- employability [8; 16; 17].

For example, the scientists L.V. Suyazova, D.A. Mustafina, I.V. Rebro, G.A. Rahmankulova underline that a competitive specialist is: 1) a professional who is ready to find the most appropriate solution for a task or a problem depending on situation; 2) a specialist who has the majority of special abilities corresponding to professional activity and whose level of professional development allows to be in demand both in the professional activity environment and in the society in total as this specialist has approved in practice the efficiency of problem solving in the continually changing environment; 3) a personality who has a system of social-oriented qualities (properties), which serve as the internal potential of achieving the results, including the ability to help, to regenerate and to use all his abilities for self-development [10].

Providing the grounds for competitiveness of a specialist, scientists speak about both personal and professional qualities, which complement each other and form one integral whole.

T. Zdanko validates the notion of competitiveness of personality as an aggregate of integral sustainable quality (for example, the activity of the rational knowledge, purposefulness, devotion for work, creativity, criticism, risking capability, stress resistance, leadership etc.), which define the success in one or another sphere of activity. The scientist is basing on the results of theoretical empirical research, including polls among employers, student as the intended specialists and the teaching staff of universities [18].

As it follows from V. Andreev, the founder of Concurentology as a new scientific interdisciplinary direction in Russia, a person becomes a competitive personality only if this person is not only able to achieve results in his activity, but also is able to become a demanded specialist in competitive environment. Among the most important attributes of competitiveness of a specialist as a professional, the scientist mentions such aspects as clear orientation in goals and values, devotion for work, creative attitude to his professional activity, ability to take a risk, independency and selfreliance, leadership, striving for constant self-improvement and professional self-development [4].

Speaking about the main features, which provide a basis for a competitive specialist, many authors are not only listing important attributes or aspects of competitiveness but are also offering their own perspective in relation to the structure of a competitive personality/specialist, identifying a number of its components.

For example, L. Mitina characterizes competitiveness as an integral whole of the personal qualities, specifying the three components of the personality structure: personality direction, competency and flexibility [5].

There are also studies conducted in relation to scientific justification for the structure of the engineer's competitiveness. For instance:

The main components of the engineer's competitiveness are as follows: professional direction, professionality level, professional development agility, ongoing eagerness for professional improvement, forcefulness and authority of a personality in the field of his professional activity. To a great extent, the competitiveness of an engineer is also determined by multi-professionalism, which is based on various kinds of competencies [9].

Based on studies in pedagogy and psychology performed by A. Bodalev, E. Klimov, B. Lomov, L. Mitina, S. Rubinshtein etc., M. Kashirin and D. Mustafina point out a number of components of the engineer's competitiveness: 1) the basic competencies of professional activity (mobility, striving for self-improvement, ability to master any of the latest technological inventions and scientific discoveries for the benefit of mankind with no threat to mankind and nature sustainability);2) awareness of the market-driven economy and professional field where the engineer is working; 3) informational or media competence (ability to find, select, analytically and critically evaluate the information necessary for professional activity in a broad and diverse information environment, implementing it in his work); 4) psychological readiness for competitive activity (professional and adequate activity in a competitive environment, professional intuition, need for successful work and achievements, sense of responsibility); 5) creativeness; 6) engineer's reflexive competence and adequate self-esteem, intrinsic necessity of professional development and improvement, ability to forecast his development and 
estimate the possibilities for the development in the professional environment; 7) self-reliance, persistence in solving of professional tasks/problems; 8) ability to solve the professional tasks/problems in a variable and rational way [19].

D.A. Mustafina, G.A. Rahmankulova and N.N. Korotkova separate the structure of the programming engineer's competitiveness, where they specify the following elements: 1) personal professional competence: purposefulness, general and specific professional knowledge, skills and abilities, self-reliance, need for achievements and successful activity, sense of responsibility, informational competence, including the ability to encode and decode the information; social competence (legal and communicative competence); 2) engineering thinking (including mechanical thinking, constructive thinking, investigative thinking, economical thinking), with such highly important features as the ability to analyse and generate, to compare and evaluate, the ability to operate with models, to thing flexibly, ability to solve ordinary and non-ordinary tasks quickly and on high quality level by implementing various technologies; 3) self-reflection and self-assessment; 4) creativity of an engineer. Each of the elements is a permanent substructure of the competitiveness structure of a programming engineer, and at the same time, all the substructures collectively are composing one integral whole [20].

The research results show that an increased focus in the models of the competitiveness structure is put on the element of competency as the competitiveness of a specialist in general, including marketability and employability, depends heavily on the versatility of competences of a specialist and on the level of development of such competences.

For example, D.V. Smotrova underlines that the competitiveness of a specialist is determined by his competency and professionalism, i.e. by his compliance with professional standards, job market demands, including the demands of employers in certain social and economic circumstances [21].

The competency of a specialist within the competitiveness context is explained as the desire, and also the ability, to implement the one's potential in practice by performing a successful, creative and efficient activity, which is reflected in both professional activity environment and social environment. The competency of a competitive specialist is reflected in own professional activity when this specialist is aware of social importance of own professional activity and understands his responsibility for the results of own professional activity, and rather than just being aware of the necessity of continuous professional improvement, a competitive specialist manages self-directed learning and professional self-development. A competitive specialist uses various methodologies, instruments and techniques in his professional activity, testing out scientific innovations, theoretical insights and hypotheses. Thus, in order to ensure own competitiveness, a competent specialist must be a sort of a researcher who introduces various innovations, makes various rationalisation proposals etc. [22].

The following competences are pointed out in the structure of competitiveness of a mechanic engineer [10]:

- professional competence (skills and abilities: 1) to master and service new equipment, 2) to work with and to prepare technical documentation, 3) to determine technical condition of equipment, 4) to analyse indices when designing new products and production technologies, 5) to plan his own work, 6) to forecast results in implementation of new technologies, 7) to improve oneself professionally, including to enlarge, enrich and correct his knowledge in accordance with changes in his professional activity area and in the job market, 8) to prepare scientific reports on the implementation of the latest research results in mechanic engineering);

- economical competence (skills and abilities: 1 ) to perform the rationalization activity; 2) to foresee the state scale and global scale changes; 3 ) to undertake the responsibility for products quality;

- personal competence (skills and abilities: 1 ) to be able to work both independently and in a team; 2) to be a responsible personality; 3 ) to be mobile and flexible, to adapt to new conditions; 4) to think in terms of success and achievements, to organise and inspire oneself and the others for the successful activity in the fast-changing environment; 5) to be creative in generating new ideas and adjusting his ideas to new requirements; 6) to develop the engineering reflection (readiness for creative evaluation of his professional activity and 
communication in case of settling problems or solving conflict situations; 7) to adapt to constantly changing system of mutual relations, 8) to set new tasks and to find for them nonstandard solutions);

- social competence (skills and abilities: 1 ) to understand the situation and to take responsibility for his decisions and actions, as well as for the decisions and actions of his personnel, 2) communication skills and abilities, including the knowledge of professional terminology in the field of mechanical engineering, to identify the problems arising during the process of his professional activity, to communicate with his subordinate employees and management in a business-like manner);

- ecological competence (skills and abilities: 1) to elaborate environmental-friendly technologies, tools and equipment, 2) to foresee the consequences of their implementation, 3 ) to forecast and to be able timely prevent technological disasters).

One more existing approach in the engineer's competency research is as follows: the basis is provided for a competitive activity of an engineer as the way of expression of his personal and professional competency. A number of various competencies and personal qualities is pointed out, ensuring the competitive activity of an engineer and his competitiveness in general: 1) motives and value orientations; 2) the desire and ability to self-development, self-realization; 3) civil qualities; 4) high professional competence; 5) leadership qualities; 6) corporate competence; 7) cultural humanitarian competence; 8) socio-economic competence; 9) creativity abilities;

\section{0) communicative competence; 11) adaptability [23].}

Thus, the competitiveness of a specialist is closely connected with his professional self-definition, professional development and self-management of his career.

For example, N. Nicholson believes that the process of development of a specialist's career consists of various stages: 1) the stage of preparation; 2) the stage of commencing professional activity, 3) the stage of adopting in the professional activity environment, and 4) the stage of stabilization of the professional activity. It is important to identify the three professional readiness types, which affect the competitiveness of a specialist in the company: 1) readiness to integrate in the professional activity environment and readiness to adopt by getting used to the new position (new job ladder); 2) readiness for unexpected turns in the professional activity, sudden situations, absence of fear of anything new; 3 ) readiness for analytical evaluating thinking (reflection) and self-regulation of his activity [24].

A specialist's competitiveness should be also associated with the creation of a professional Iconcept and professional identity [25], where the aggregate of views of a specialist regarding the notion of a sought-after specialist is of key importance.

A number of scientists underline the high importance of education for the intended specialists and the professional improvement for acting specialists. The following learning theories and conceptions are identified in promoting of competitiveness: 1) Experience Based Learning or Experiential learning [26-28]; 2) Work Based or Workplace Based Learning [29 -30]; 3) Problem-Based Learning [31]; 4) Student-Centered Teaching and Learning Strategy, Active Learning [32]; 5) Self-directed Learning [33].

In the process of professional development of a competitive engineer and self-management of his career progression, a special place is held by self-direction learning. Readiness for self-direction learning and readiness for professional self-development are the important characteristic criteria of an engineer as a competitive specialist. Nowadays the self-direction learning attracts the attention of many researchers. Some scientists call the self-directed learning as self-regulated learning and/or selfmanaged learning. Self-managed or self-directed learning means that the learner takes personal initiative in the learning process, without any active participation of an educator. The self-directed learning has a cyclical nature, as the learner himself plans, implements and evaluates his goal-oriented, motivated learning as a process and its results, which is especially typical to the learning process of the adult learners. 


\section{Conclusions}

1. The competitiveness of an engineer in pedagogical and psychological sciences is based on the three aspects: the competitiveness of a personality; the competitiveness of a specialist in the broad sense of the term; the competitiveness of an engineer, focusing on the engineer's specialization area in the engineering science.

2. Various tendencies are observed in the validation of the engineer's competitiveness, such as: 1) the competitiveness of an engineer is defined in terms of the competitiveness of a personality and the competitiveness of a specialist; 2) the attributes or the qualities of an engineer's competitiveness are identified; 3 ) the models of the engineer's competitiveness are created and scientifically grounded, identifying its various elements; 4) in the opinion of many scientists, the competency (including professional competence) is one of the most important elements of the engineer's competitiveness structure.

3. The notion of the engineer's competitiveness is often replaced by the notion of marketability and employability.

4. It is important not only to study the engineer's competitiveness but also to provide the scientific grounds for the ways of its promoting during the process of education and professional improvement based on modern theories and concepts: Experience Based Learning or Experiential learning; Work Based or Workplace Based Learning; Problem-Based Learning; Student-Centered Teaching and Learning Strategy, Active Learning; Self-directed Learning.

\section{References}

1. Apressyan R.G. Business Ethics in Russia. Journal of Business Ethics, vol. 16 (No. 14), 1997, pp. 1561-1570.

2. Katane I. Competitiveness of Personality as a New Concept in Modern Education and Pedagogy Science. Proceedings of the 9th International Scientific Conference "Engineering for Rural Development", Vol. 9, May 27-28, 2010, Jelgava, Latvia, pp. 327-334.

3. Katane I., Kalniņa I. Skolēnu konkurētspējas attīstība neformālās komercizglìtības vidē [Monogrāfija] (Development of Pupils' Competitiveness in Environment of Commercial Education [Monograph]). Jelgava: LLU TF IMI, 2010. 331 lpp. (in Latvian)

4. Андреев, В. И. Конкурентология (Concurentology). Казань: Центр, 2006. 470 с. (in Russian)

5. Митина Л.М. Психология развития конкурентоспособной личности (Developmental Psychology of the Competitive Personality). Москва: МПСИ, 2003. 400 c. (in Russian)

6. Katane I. Methodological Bases for Evaluation of Specialist Competitiveness. Proceedings of the 10th International Scientific Conference "Engineering for Rural Development", vol. 10, May 26 27, 2011a, Jelgava, Latvia, pp. 524-529.

7. Katane I. Philosophic Methodological Bases for Evaluation of Educator's Competitiveness. Proceedings of the 17th Annual International Scientific Conference "Science for Rural Development", vol. 2, May 18-20, 2011b, Jelgava, Latvia, pp. 218-224.

8. Zaussinger S., Unger M., Thaler B., Dibiasi A., Grabher A., Terzieva B., Litofcenko J., Binder D., Brenner J., Stjepanovic S., Mathä P., Kulhanek A. u.a. Studierenden-Sozialerhebung 2015 (Sociological Survey among Students 2015). Bericht zur sozialen Lage der Studierenden. Band 2: Studierende. Wien: Institut für Höhere Studien (IHS), 2015, S. 427. (in German). [online] [01.03.2017]. Available at: http://www.ihs.ac.at/publications/lib/IHSPR6861196_II.pdf

9. Арзуманян А. К. Психологические аспекты конкурентоспособности инженеров (Psychologic Aspects of Engineers Competitiveness). В: О. Н Широков и. др. (ред.). Материалы VIII Междунар. науч.-практ. конф. Современные методы и практика теории развития образования (Modern education development theory techniques and practice). № 2 (8). (Чебоксары, 31 июля 2016 г.). Чебоксары: ЦНС «Интерактив плюс», 2016. с. 42-44. (in Russian)

10. Суязова Л.В., Мустафина Д.А., Ребро И.В., Рахманкулова Г.А. Структура конкурентоспособности будущего инженера в машиностроении (The Structure of Competitiveness of an Intended Engineer in Mechanical Engineering). Международный студенческий научный вестни, 2013. (in Russian). [online] [12.03.2017]. Available at: https://www.eduherald.ru/ru/article/view?id=70 
11. Briede B. Concepts, research aspects and kinds of competence, Professional competence and Professionalism. Proceedings of the 4th International Scientific Conference "Rural Environment. Education. Personality (REEP)", vol. 4, May 29 - 30, 2009, Jelgava, Latvia, pp. 503-512.

12. Briede, B., Pēks, L. A constructivist approach in teaching in higher education for getting methodological and reflection competences. Proceedings of the 7th International Scientific Conference "Rural Environment. Education. Personality (REEP)", vol. 7, February 7-8, 2014, Jelgava, Latvia, pp. 84-89.

13. Tiḷıa I. (2005). Socālkultūras mācī̌anās organizācijas sistēma. Rīga: RaKa, 294 lpp.

14. Зимняя И.А. Ключевые компетенции - новая парадигма результата современного образования (Key Competences - New Paradigm of Results in Modern Education. Интернетжурнал “Эйдос”, Мay 5, 2006. [online] [21.04.2017]. Available at: http://www.eidos.ru/journal/2006/0505.htm

15. Swanepoel B., Erasmus B., Van Wyk. M., Schenk H.W. South African Human Resource Management: Theory \& Practice. Cape Town: Juta \& Co Ltd, 2003. 889 p.

16. Turner D. Employability skills development in the United Kingdom. London: NCVER Ltd., 2002. [online] [11.03.2017]. Available at:

https://www.ncver.edu.au/_data/assets/file/0022/9751/employability-skills-development-777.pdf

17. Teijeiro M., Rungo P., Freirea M. J. Graduate competencies and employability: The impact of matching firms' needs and personal attainments. Economics of Education Review, vol. 34, 2013, pp. 286-295. http://dx.doi.org/10.1016/j.econedurev.2013.01.003

18. Жданко Т.А. Образовательно-профессиональное пространство вуза как педагогическое условие формирования конкурентоспособности личности студента (Educational and Professional Environment of a Higher Education Institution as a Pedagogic Provision for a Competitive Student's Personality). Автореф. дис. ... канд. пед. наук. Чита, 2011, 24 с. (in Russian)

19. Каширин М.С., Мустафина Д.А. Признаки конкурентоспособности инженера (The Criteria for Competitiveness o fan Engineer). Успехи современного естествознания, 5, 2012, с.75-76. (in Russian)

20. Мустафина Д.А., Рахманкулова Г.А., Короткова Н.Н. Модель конкурентоспособности будущего инженера-программиста (A Model of Competitiveness for an Intended Programming Engineer). Современные наукоемкие технологии, 8, 2010, c.16-20. (in Russian)

21. Смотрова Д.В. К вопросу об определении понятия "конкурентоспособность личности“. Magister Dixit: Научно-педагогический журнал Восточной Сибири, 2 (No. 06), 2012, (in Russian). [online] [21.02.2017]. Available at: http://md.islu.ru/ru/journal/2012-2

22. Юрова Н. В. Конкурентоспособность специалиста и факторы ее определяющие (The Competitiveness of a Specialist and its Determining Factors). В материалах XII Международная научно-практической конференции „Актуальные проблемы бизнес образования", 19 апреля, 2013. Минск: Белорусский Государственный университет, Институт бизнеса и менеджмента. (in Russian). [online] [23.02.2017]. Available at: http://www.sbmt.bsu.by/Data_RUS/ContBlocks/01464/KONKURENTOSPOSOBNOSTJSPECIALISTA-I-FAKTORY-EE-OPREDELJAJUSCHIE.pdf

23. Khairullina E.R., Pochinova T.V., Khisamiyeva L.G., Sakhipova Z.M., Fedorova L.V., Ablyasova A.G. \& Aksenova N.N. The Competences Model of Competitive Process Engineer. Journal of Sustainable Development, vol. 8 (No. 3), 2015, pp. 250 - 255.

24. Почебут Л. Г., Чикер В. А. Организационная социальная психология (Organisational Social Psychology). СПб.: Речь, 2000. 358 с. (in Russian). [online] [20.02.2017]. Available at: http://pedlib.ru/Books/1/0139/index.shtml?from_page=160

25. Рикель А.М. Профессиональная Я-концепция и профессиональная идентичность в структуре самосознания личности (The Professional I-Concept and Professional Identity in the Personal Self-Awareness Structure). Часть 1. Психологические исследования, Vol. 2 (No. 16), 2011. (in Russian). [online] [19.02.2017]. Available at: http://psystudy.ru/index.php/num/2011n216/457-rikel16.html

26. Ghose N. Enhancing Global Competitiveness Through Experiential Learning: Insights Into Successful Programming. American Journal of Business Education, vol. 3 (No. 7), 2010, pp. 1-6. [online] [12.03.2017]. Available at: http://files.eric.ed.gov/fulltext/EJ1058566.pdf 
27. Pascual R., Uribe R.Experiential Learning Strategies in a Mechanical Engineering Senior Course. In Sixth International Workshop on Active Learning in Engineering Education, 2006. [online] [19.03.2017]. Available at:

http://citeseerx.ist.psu.edu/viewdoc/download?doi=10.1.1.474.2497\&rep=rep1\&type=pdf

28. Nenzhelele T.E. Employability through Experiential Learning Course in Open Distance Learning Institution. Mediterranean Journal of Social Sciences, vol 5 (No. 20), 2014, pp.1602- 1612.

29. Aslin, P., Challis, M. and McEwan, P. The Role of Work-Based Learning in Engineering Degree Programmes. Capability, vol. 1 (No. 3), 1995, pp. 31-38.

30. Nikitin A.A., Palyanov M.P., Morozova M. V., Markovichev A. S. The Management of Advanced Training of Engineering and Technical Specialists Based on the Interaction between Universities and Business-Structures. International Review of Management and Marketing, 2016, vol. 6 (No. $1), 75-80$.

31. Beagon U., Niall D. Using Problem Based Learning to Develop Graduate Attributes in First Year Engineering Students. Dublin Institute of Technology, 2015. [online] [19.03.2017]. Available at: $\mathrm{http} / / /$ arrow.dit.ie/cgi/viewcontent.cgi?article=1093\&context=engschcivcon

32. Barte G.B. Implementation of Microelectronics Track in Electronics Engineering in a Philippines State University. Asia Pacific Journal of Multidisciplinary Research, vol. 3 (No. 4), 2015, pp. $66-71$.

33. Bary R, Rees M. Is (self-directed) learning the key skill for tomorrow's engineers? European Journal of Engineering Education, vol. 31, 2006, pp. 73-81. 